\section{Exposing the contradictions}

IT IS good to see that Pacific Journalism Review is being relaunched at Auckland University of Technology and I congratulate David Robie for spearheading this project. When I was an AUT journalism lecturer, I used to use excerpts from $P J R$ articles in the Public Affairs Reporting course for which I was responsible, especially in relation to indigenous and 'ethnic' media.

The new PJR will be broader in scope and I welcome this too. There is a need for an analytical journal that examines the media, both from the point of view of the media 'consumer' and those engaged in 'production' of the news.

I hope practitioners will contribute to $P J R$ as well as academics, because I believe we need to hear from journalists who are reflecting on their practice and the political and economic context of their work.

This is a critical time for the media in New Zealand, highlighted perhaps by the recent sacking of Malcolm Evans by the New Zealand Herald because his cartoons drew too much attention to the plight of the Palestinian people. It was a disgraceful affair that highlighted the hypocrisy of our media barons who defend the concept of a 'free press' when their capitalist interests are threatened, but who are prepared to abandon those principles and bow to the power of the Zionist lobby.

Academics too are not immune to such power. This became clear to me last year when I was attending the National Tertiary Education Union conference in Melbourne (the NTEU is the Australian equivalent of my union, ASTE).

Some members tried to include a reference to the situation in Palestine in a resolution relating to the imminent invasion of Iraq. But others spoke from the floor about the amount of research funding that goes into Australian universities from Zionist organisations. To pass such a resolution, they said, could alienate that lobby and cost academics their jobs. It was an outrageous argument, but the reference was dropped nonetheless. It was thought to be too divisive.

In New Zealand, we stand proud of our record opposing apartheid in South Africa, but we are far too quiet about the walls being built around 
Israeli settlements that restrict the freedom of Palestinian people to work, to attend school, to go about any semblance of normal life.

I have a poster on my wall that shows a little Palestinian boy throwing stones at an Israeli tank. The poster states: 'When you find yourself sending tanks into refugee camps, it's time to reconsider where terror begins.'

I know PJR will have the courage to expose the contradictions of the 'Fourth Estate'. I firmly believe 'sunlight is the best disinfectant' and there are things in our world that need to be exposed to such light. I look forward to working together where possible.

\section{Jill Ovens}

\section{Editor}

\section{Red \& Green,} the NZ Journal of Left Alternatives

\section{Congratulations}

I WANT to congratulate you on the relaunching of Pacific Journalism Review out of Auckland. This is so fitting as Auckland is becoming the hub for Pacific media. Not only is our city the biggest Polynesian city in the world, but there is nowhere else where there is such a great mix of Pacific Island peoples.

$P J R$ has been one of my most helpful resource publications as it deals with relevant issues.

\section{Kalafi Moala}

\section{Publisher, Taimi ‘o Tonga}

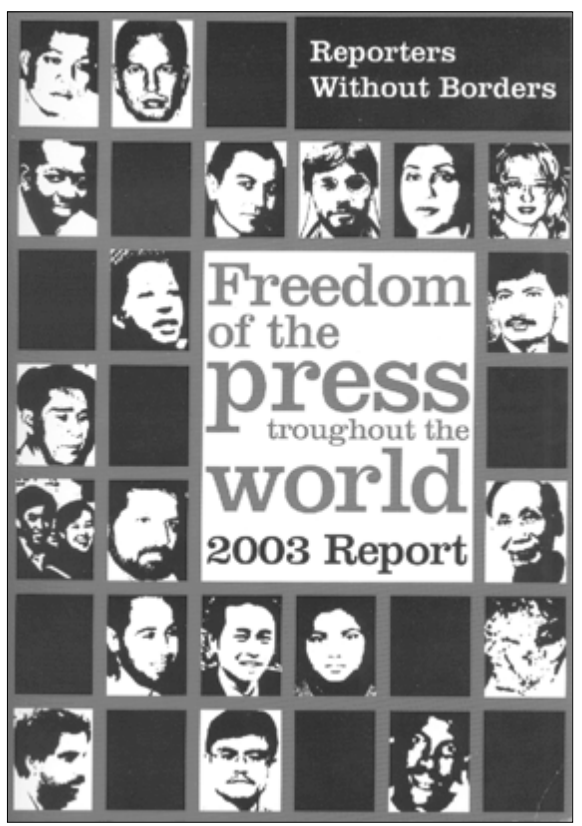

\section{Covering conflict}

- From Page 203

lies, deception and manipulation of information in a climate of war and violence, the International Federation of Journalists has published a timely and practical guide for those covering conflict. Aptly entitled, Live News: A Survival Guide for Journalists, the 136-page book includes chapters on preparing to work in hostile environments; war zones and conflict areas; riots and civil disorder; abductions, hostage taking and targeting journalists; emergency medical aid; and posttraumatic stress disorder. Finally, there is a helpful chapter on how we can 'fight back' - by sharing safety training, knowhow and experience. 